\title{
Foreign Direct Investment and Spillover Effects in Africa: An Empirical Review
}

\author{
Richard Angelous Kotey \\ Department of Finance \\ University of Ghana Business School
}

Ghana

\begin{abstract}
The purpose of this paper is to holistically present relevant empirical findings on FDI, economic growth and spillover effects in the African continent, focusing primarily on technology transfer. This review shows evidence to suggest the FDI coming into Africa is low compared to other continents, even though foreign investments have consistently yielded higher returns. The paper also presents stylized facts of FDI inflows and examines the strands in literature. Aunique graphical framework showing technology transfer channels is well elaborated. The study provides a sufficient empirical view of FDI and technology transfer in the African contextand suggests this transfer of technology could be the means of bridging the technology gap between developed and developing economies.
\end{abstract}

Keywords: Foreign Direct Investment, Stylized Facts, Technology spillover

JEL classification: $F 21, O 11,033$

\section{INTRODUCTION - FOREIGN DIRECT INVESTMENT IN AFRICA}

FDI has been a viable source of foreign investment or capital inflows into Africa to finance long term developments, aside financial assistance from international bodies like the IMF. Capital inflows from the latterhave come saddled with austerity measures, most of which are generalized conditions that do not agree well with the local context, which tend to stifle the full economic impact of these loans. So, African countries are left to seek recourse in FDI inflows which do not come with such austerity measures.

Foreign Investment has therefore assumed a prominent role in mitigating the challenges of low economic growth and high poverty levels faced by the continent. It is no wonder economic strategies preached by policymakers at the macro front (the national, regional and international levels) seek to attract FDI as the tool through which the former can be achieved. Also, developing economies that have gyrated to the forefronts of economic developments, like China, have re-emphasized the notion that receiving FDI is important in bridging the resource gap of low-income countries and also reducing debt accumulation while trying to reduce poverty[34]. Again, this notion has been promoted in developing economies that FDI inflow is a viable channel, or perhaps the only viable channel, for not only consistent and stable capital inflows but also a means for technological knowledge, new skills and other benefits like export opportunities [56].

The efforts of African countries or governments to attract and foster FDI relations has been un-achieving. Statistical records over the past two decades or so with respect to reducing poverty and attracting FDI has not been encouraging when compared with other continents. It is true Africa has been commended these few years for gradually increasing its growth rate from $3 \%$ to about $6 \%$ but such a feet, when compared with other developing regions in its proper context is abysmal. Take 2014 for example, the amount of net FDI inflows around the world was about $\$ 1.678$ trillion. Of this amount only $\$ 44$ billion representing a mere $2.6 \%$ of the whole chunk came into Sub-Saharan Africa with the rest going to Asia (about 38.8\%), Europe (about 27.6\%), Latin America (about 28\%) and North Africa and the Middle East (about 3\%). But, surprisingly, Africa has consistently offered higher returns on investments. This contrast between higher interest rates on foreign investments and lower foreign investment 
flows into Africa is not limited only to that period alone, but has become the narrative of the nature and size of FDI inflows into Africa.

A significant number of studies have been done examining FDI into Africa from different facets. Yet, a holistic examination of empirical data and findings on the subject is still lacking. This paper is unique in that it brings to bear empirical findings of relevant literature examining key issues and conceptualizing the linkages. We examine stylized facts of FDI coming into Africa, the linkage between FDI and growth, FDI and technology and conceptualize the spillover channels and how they interrelate.

\section{TECHNOLOGY AND FDI}

Technology, as used in this paper refers to new knowledge, methods and innovative procedures, acquired mostly through research and development engagements, which has the capability of increasing output or productivity. It includes but not limited to knowledge creation, management know-how, efficiency in the production process, product innovations, and others. This technology when applied to production increases output. It is not surprising that studies on technology have been linked to productivity ([10], [13], [24], [12]).

New technology and innovations require huge capital investments, specialized skills (or human capital) and other characteristics to be present in the host country. The cost of such an endeavor alone is a challenge for developing economies to bear. So most developing economies depend on FDI as a means to gain access to some of these technologies ([24], [35]). It is because large MNC's have the financial and technical wherewithal to engage in technology-producing research. MNC's own, control and produce over $80 \%$ of the world's technology[12]. Eminent scholars have found out that when a country interacts with MNC's through foreign investments (FDI), some of the technology and knowledge rub-off on the local firms ([24], [32], [8]). Technology can be transferred across countries through international trade; through the transfer of specialized goods and services, leasing and franchising agreements and FDI, technology and intellectual property may be transferred. However, FDI is the most effective method of transfer because, through FDI, technologies that are hard to measure or obtain can be transferred to local economies[32]. Therefore by encouraging MNC investments through FDI, technology from FDI can diffuse to local firms.

MNCs play a major role in global innovation. According to a UNCTAD report in 2005, one half of the world's total expenditure in R\&D comes from MNCs. This figure increases to more than two thirds when considering R\&D for the business sector only [34]. It is, therefore, no surprise that about 80 percent of the world's technologies are owned by MNCs as cited earlier[12]. The MNCs who spend the most in R\&D are usually concentrated in Information Technology (IT) and software development industries, the automotive industries, mobile phone industries, and pharmaceuticals industries. Table 1 shows the Research and Development expenditure for some MNCs for the year of 2009 alone.

TABLE 1 R\&D EXPENDITURE OF SELECTED MNCS AND OTHER COUNTRIES

\begin{tabular}{lclc}
\hline \multicolumn{1}{c}{ MNC } & $\begin{array}{c}\text { R\&D Expenditure (in } \\
\text { million \$) }\end{array}$ & \multicolumn{1}{c}{ Countries } & $\begin{array}{c}\text { R\&D Expenditure in } \\
\text { 2009 (in million \$) }\end{array}$ \\
\hline Toyota & 9403 & United States *(2013) & 473400 \\
Microsoft & 8437 & China *(2015) & 409000 \\
VW & 8043 & Germany & 11799.795 \\
Pfizer & 7507 & United Kingdom & 8731.631 \\
Novartis & 7163 & Japan & 4185.27 \\
Nokia & 6942 & Canada & 3639.433 \\
Johnson \& & 6764 & & \\
Johnson & & Sweden & 3251.971 \\
Samsung & 6265 & Brazil & 343.547 \\
Electronics & 5875 & Ethiopia & 5.474 \\
General Motors & 5857 & South Africa *(2012) & 4.800 \\
Honda Motors & & &
\end{tabular}




$\begin{array}{lclc}\text { Daimler } & 5785 & \text { Botswana } & 1.946 \\ \text { Intel } & 5473 & \text { Rwanda } & 0.238 \\ \text { Sony } & 5172 & \text { Côte d'Ivoire *(2010) } & 0.141 \\ \text { IBM } & 4787 & \text { Benin } & 0.038 \\ \text { Takeda } & 4712 & \text { Togo } & 0.022 \\ \text { Pharmaceutical } & \text { Author's own computation. R\&D expenditure of selected MNCs and countries in 2009. Source [35] }\end{array}$

Much of the researches MNCs undertake is usually done in developed economies. Little or no research is done in developing economies. This accounts for the technology gap between the developing and developed economies([10], [17], [23], [24], [29], [32]). However through interaction between MNCs and local firms in developing economies, particularly through direct investments, knowledge and technology trickle down or diffuses to local firms, particularly through mechanisms like imitation, competition, backward and forward linkages.

\section{ECONOMIC GROWTH AND FDI}

The effect of FDI on economic growth is well documented as more studies continue to be conducted across the globe. The relationship between FDI and economic growth has been positive in more studies with varying degrees of significance. However, in the African context, the relationship can be negative.

Empirical literature on FDI and economic growth can be categorized into three strands; the first strand entails studies on FDI and growth in developing countries, where certain characteristics (or absorptive capacities) are tested because of expectation of their contribution towards absorption.

The second strand of literature looks into the causal relationship between FDI and economic growth. Thistype of research seek to unravel whether FDI causes economic growth or economic growth attracts FDI. The later holds in situations where MNCs invest in economies that have high growth rates([22], [7], [11], [26], [23]). For example, Choe [11] found a bi-causal relationship between FDI and economic growth. He sampled 80 countries over a period of 25 years (1971-1995). Using a panel VAR model, that FDI inflows Granger causes economic growth and economic growth also granger causes FDI. However, the Granger causality is stronger for economic growth causing FDI. Using Ghanaian data, Kombui and Kotey [22]also found that interest rate, natural resource endowment, government expenditure, inflation, infrastructure, and international reserves granger causes FDI.

The third strand of research looks at issues other than those found in the two strands. Examples include studies on how the volatility of FDI affects economic growth ([27], [36], [28]). Nair-Reichert and Weinhold[27] looked at the relationship between FDI and economic growth from country to country. They sampled 24 developing countries for 25 years (1971 to 1995) using fixed effects and random effects. Their results were that there is a causal relationship between FDI and economic growth and FDI is higher in countries with open economies than those that don't have open economies.

\section{STYLIZED FACTS ON FDI}

This sub-section proceeds to list a number of stylized facts that have become accepted as empirical truths to which theories must be made to fit. A lot of studies done in Africa adopt these stylized facts. These facts have a bearing on the theory adopted for this study and how the interpretations of the results are done.

\section{A. $\quad$ FDI is an important source of finance for SSA}

Compared to official loans that SSA receives, FDI inflows have increased substantially over the years exceeding the former when partially substituted for. Asiedu[4] cites that from 1990 to 1999, net official loans have declined by about $24 \%$ whilst within the same period, FDI inflows have increased by about $180 \%$. Sufficed to say that Africa has more appetite for FDI rather than foreign loans that come with complex regulations and requirements. However, Africa it seems has received a much lower percentage of the FDI inflow in proportion to the whole world. The amount of FDI that comes to SSA is among the least FDI inflows received by any developing region. To infer from [4]again, within a decade (1990-1999), the amount of FDI going into developing countries 
increased by over $1600 \%$. In the case of Africa, the increase in FDI inflows was only about a $490 \%$ fold. That's about only $37 \%$ of what other developing countries are getting.

\section{B. Return of FDI from Africa is much higher than other continents}

Studies like [4] and others have shown that return on investment (ROI) is much higher for African countries compared to other developing countries. Some authors have attributed this phenomenon to weak institutions and policies, international trade agreements (like AGOA), production inputs and the nature of the political climate in the economy ([2], [63], [6]). Take the study done by[6]from the Research and Statistics Branch of UNIDO, using principal component factor analysis concluded in their study that the primary concern of foreigners investing into SSA is the stability of the political economy to spur growth through sound investment and the proper functioning of rule of law (thus the transparency of legal framework). Their findings remain unchanged even after they put in controls for two clusters of the host countries.

A similar report, by UNCTAD titled Economic Development in Africa also stipulated that, although weak institutions are the cause of this outcome, it could also be a potential advantage to countries who will make the efforts to improve their governance institutions to look favourable in the eyes of the business world.

\section{Technology from FDI is of immense importance to SSA}

Most developing economies do not have the required human capital and capital investment to create new innovations and technology[35]. For there to be any chance of narrowing the technology gap, it behooves on these economies to absorb these innovations from MNCs through foreign investment. Of the various empirical methods of measuring technology, in Africa, the data is scanty because of this. This is because not much R\&D is done on the continent partly because of the capital requirements for such endeavours. Not surprisingly, the Africa investment report in 2015 stated that FDI on R\&D has decreased year on year for 4 years with only one project recorded in 2014 resulting in a capital investment decline of 82\% in 2014. Therefore, Africa (and other developing economies) tend to benefit from the contagion of technology from trading with MNCs. Policy makers factor this in the regional and national policies they implement.

However, empiricists have shown that for there to be spillover of contagion of these technologies, there must be certain macro and micro factors present; there must be human capital that can absorb this knowledge, local firms should have had some form of training from MNCs, local firms should have some closeness or interaction with MNCs through the value chain. A well-cited paper [32] indicates empirically that for spillover to occur, local firms must have the necessary characteristics to absorb them. So not only is technology spill from FDI's important, but local firms must be equipped to absorb them.

\section{SSA countries do not receive much FDI despite the fact that they have a higher return on investment}

The amount of FDI that comes into Africa is not commensurate with the returns (expected and actual) that the investment is able to churn out. For example, the average return on investments from US FDI alone coming to Africa in the 1990s was about 30\%, the highest return from developing regions even though just about $2 \%$ of total FDI was received by Africa. Returns continued to increase significantly over the next decade. The average return on investment from Asia Pacific was 21\%; 14\% for Latin America; 16\% for all developing economies[4]. In 2014, the United States invested a total of 97 projects in Africa, a 48\% increment from the number of projects in 2013, costing US\$ 7.9 billion. To put things in perspective, the total amount of FDI that came into Africa in 2014 was US\$ 87 billion (includes estimates, as reported by the Africa Investment Report, 2014). This figure, although huge is dwarfed by FDI that go into other developing economies; 470 billion worth of FDI was invested in Asia and Oceana; 170billion into Latin America and the Caribbean. This indicates that there exist a paradox of high returns and low foreign investments in Africa. 
TABLE 2 AFRICA'S FDI IN PERCENTAGES

\begin{tabular}{lcccc}
\hline Africa's FDI & $\mathbf{1 9 7 0}$ 's & $\mathbf{1 9 8 0}$ 's & $\mathbf{1 9 9 0 ' s - 2 0 0 4}$ & $\mathbf{2 0 0 5 - 2 0 1 5}$ \\
\hline As a \% of FDI in Developing Economies & 19.53 & 10.74 & 6.67 & 8.42 \\
As a \% of FDI in the World & 4.72 & 2.37 & 1.89 & 3.39 \\
\hline
\end{tabular}

Authors own computation. Source UNCTAD database.

The average FDI inflows to Africa has significantly increased from about US\$1.124 billion in the 1970s, representing about $20 \%$ of total FDI received by developing economies. It doubled to about US\$2.201 billion in the 1980 s, then quadrupled to an average of US\$ 9.883 billion from the 1990s to 2004. However average FDI received by developing economies in the 1980s stood at about 20.5 billion, an increase of about 4 times the amount of FDI inflows it received in the 1970s. The amount Africa received dropped from $20 \%$ to about $11 \%$ from the 1970s to 1980s. In the 1990s to 2004, average FDI in developing countries increased to about US\$148.193 billion. Africa received only about 7\% of this amount, with Asia receiving most of it (over 60\%). From 2005 to 2015, FDI to developing countries has increased to about 4 times to 580 billion. But the average FDI received into Africa remains at about $8 \%$, receiving only US\$ 49 billion. This is an indication of Africa's marginalization as the world continues to increase international trade and development. Africa's FDI, in terms of percentage to the world, has steadily declined from about $4 \%$ in the 1970 's down to about $1 \%$ on the 1990 s and marginally increased to about $3 \%$ in the 2000s.

\section{FIGURE 1 FDI INFLOWS: AFRICA AND THE WORLD}

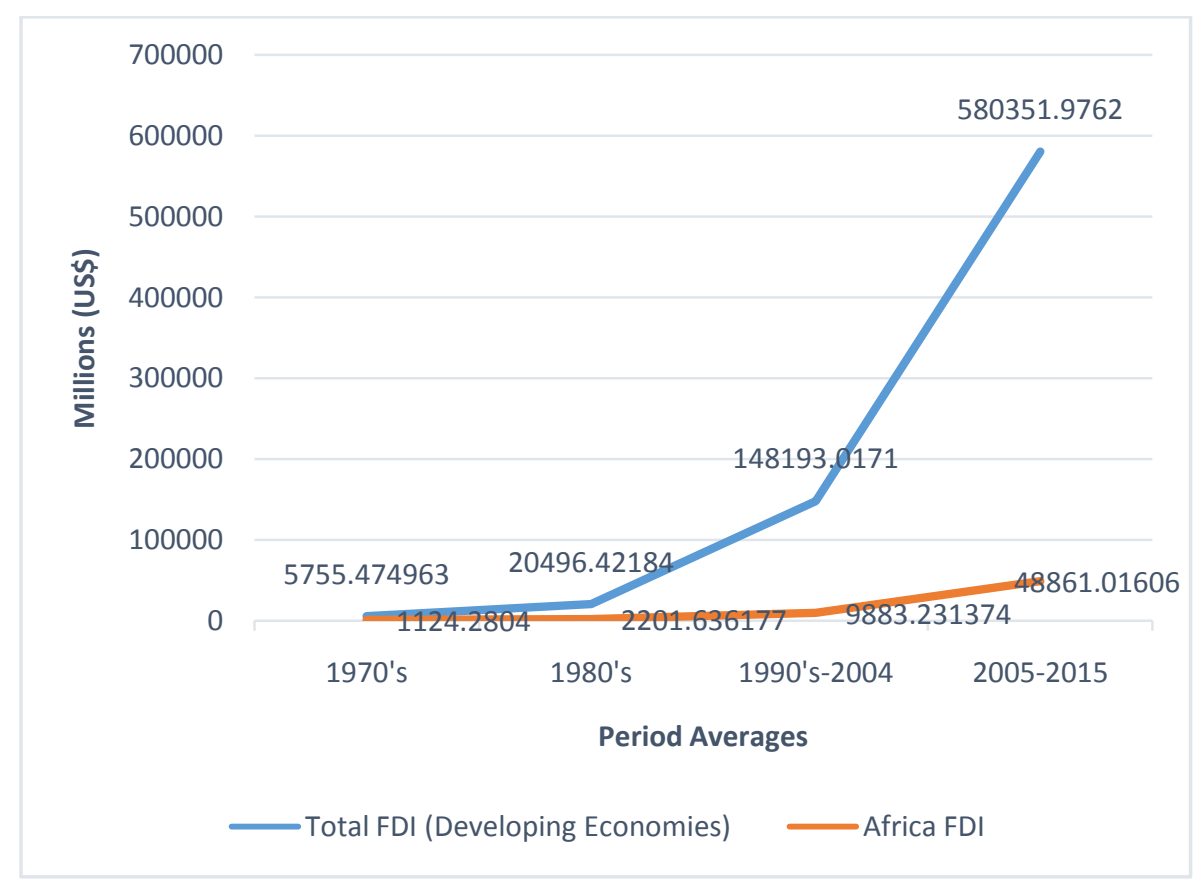

Authors own computation. Source: UNCTAD database.

\section{E. Political Stability affects FDI inflow into SSA}

There is empirical evidence that suggests that foreign investors, particularly those that invest in the African continent, see political factors as a risk pertinent to investment. To safeguard their investments, they want to ensure that the legal framework in the country is not weak. Researchers have observed this phenomenon and have well documented it in literature. In researching for this study, the author found that most studies on FDI and economic 
growth conducted using data from Africa did control for political stability (see[2], [1], [10]). This study also includes a variable to measure or controls for strength or weakness of the political environment and how it affects our results.

F Bulk of FDI coming into Africa are centered on manufacturing and extractive sectors of the economy FDI investments coming into Africa largely go into the raw material industry than the service and finished goods industry. As identified by [6], there exist some form of asymmetries in the African region as the bulk of its FDI inflows go into the primary sector. Again [4], distinguishes FDI into two forms; market-seeking FDI and non-market seeking FDI. With market-seeking FDI, FDI is invested in sectors that serve the demand of the local market. Such economies are characterized by high demand, high-income levels, and large markets. Non-market seeking FDI does not need to meet the needs of the immediate local market, but rather the external market. As such FDI is not affected by market size, income or demand. It, therefore, presupposes that FDI coming into small and developing economies as most likely not market seeking. FDI coming into developing economies, like SSA, will focus mostly on the extractive and manufacturing sector - for the external market.

TABLE 3 FDI INFLOW INTO AFRICA (BY SECTORS)

\begin{tabular}{lcc}
\hline FDI Inflows by Sectors & $\begin{array}{c}\text { US\$ } \\
\text { (Billion) }\end{array}$ & $\begin{array}{c}\text { Market } \\
\text { Share (\%) }\end{array}$ \\
\hline Manufacturing & 28.7 & 33 \\
Extraction & 22.2 & 26 \\
Construction & 12.5 & 14 \\
Electricity & 10 & 12 \\
ICT and Internet Infrastructure & 6.2 & 7 \\
Logistics, Distribution and & & \\
Transportation & 2.6 & 3 \\
Business Services & 1.7 & 2 \\
Sales, Marketing and Support & 1.6 & 2 \\
Headquarters & 0.3 & 0.4 \\
Recycling & 0.2 & 0.3 \\
Other sectors & 0.5 & 0.3 \\
Total & 86.5 & 100 \\
\hline \multicolumn{2}{l}{ Author's own computation. Data Source: Africa investment report 2015. }
\end{tabular}

The Africa investment report, 2015, reports that in Africa- the manufacturing sector received the highest FDI of US\$ 28.7 billion in 2014 representing 33\% of the market share. It said the number of projects in the manufacturing sector and its market share grew slightly by $3 \%$ in the year. The next three sectors in the economy that received higher FDI were; the mining and oil drilling (Extraction) industry received 22.2 billion accounting for $26 \%$ of the market share; the real estate (construction) industry also received 12.5 billion representing $14 \%$ of the market share; the electricity industry received 10 billion representing $7 \%$ of the market share. The Construction sector experienced a 60 percent growth in project numbers in 2014. These accounts show the importance of the raw materials sector in attracting FDI into the continent.

\section{FDI INFLOWS INTO AFRICA: A TREND ANALYSIS}

As has been shown, FDI inflows that come to the African continent have been minimal over the years. For example, from 2005 to 2010, the average FDI inflow into developing economies was $35.72 \%$ of the total FDI inflows in the world. Of this amount, only 3.30\% came into Africa. The figure reduces to $2.97 \%$ when North Africa is taken out. 
The figure below gives a pictorial representation of FDI inflows over an 11-year period from 2005 to 2015 . FDI inflows going into developing economies plummets from 2005 to 2008 from $35 \%$ down to $28 \%$, then picks up from 2008 going up as high as 55\% in 2014 where it exceeds FDI inflows into developed economies. In 2015 FDI then plunges down to $43 \%$. Within a period of over a decade, FDI inflow into SSA countries has been between $1.5 \%$ to $3.5 \%$ of the total FDI inflow around the world. Put differently, FDI entering developing economies have increased by about $445 \%$ during this period. Of this increase, $67 \%$ went into Asia and Oceana, $24 \%$ went into Latin America and the Caribbean. Only $6 \%$ was received by SSA.

So whiles FDI received by developing economies gradually increases over time gaining an upward progression, the percentage of growth of FDI coming to SSA, when observed in continuum smoothens out. In 2013 to 2014, when the amount of FDI into developing economies superseded the amount going into developed economies, the percentage change (in this case, increment) was about $14.75 \%$, observed as a spike in the figure below. FDI to Asia and Oceana, within that period, increased by $20.9 \%$ and Latin America increased by an $8.11 \%$ change. SSA increased by a percentage change $29.2 \%$, representing only an increment of $0.84 \%$ in the amount of FDI into SSA (from $2.88 \%$ to $3.72 \%$ ). SSA received the increment in FDI of about US\$ 6.417 billion whilst Asia's FDI increased by 35.660 billion. This shows an unfavourable marginal increase in FDI to SSA countries compared to other developing economies.

\section{FIGURE 2 FDI INFLOWS (IN PERCENTAGES) TO DEVELOPING ECONOMIES FROM 1970'S-2015}

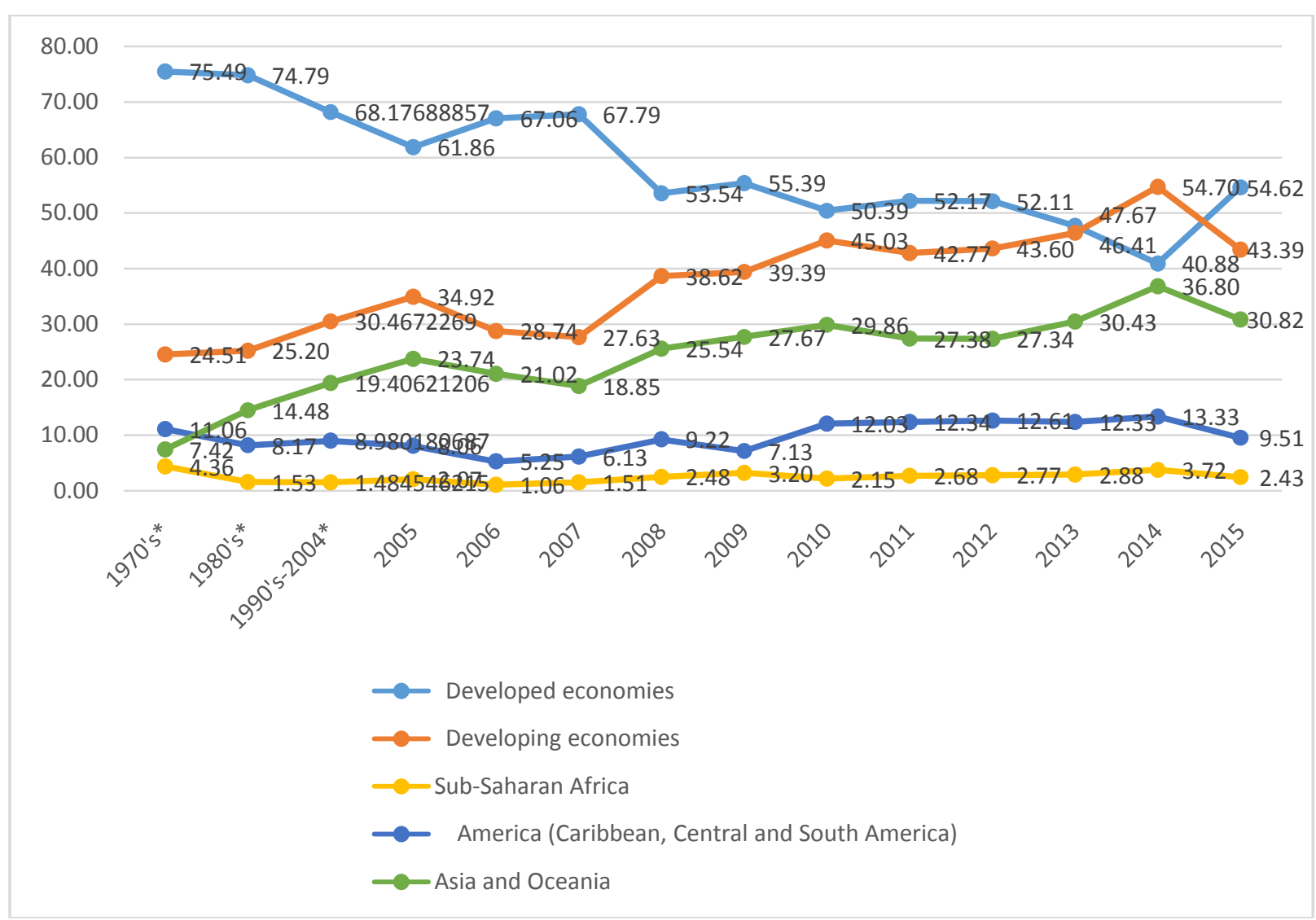

Authors own computation. Data source: UNCTAD database. 


\section{FORMS OF TECHNOLOGY TRANSFERS FROM MNCs}

From literature, forms of technology spillover occur in two primary ways - horizontal and vertical. Each form has peculiar characteristics. The author elaborates more on them.

\section{A. Horizontal Spillovers}

Technology spillover is termed as horizontal when MNCs technology is absorbed by local firms within the industry in which the MNCs operate[21]. This diffusion is intra-industry as it occurs between firms at the industry level, hence the name horizontal. Under horizontal spillovers, knowledge externalities are transferred through the demonstration effect (DE) and competition effect (CE).

\section{Demonstration Effect (DE)}

Under the Demonstration Effect (DE), the local firms (in the industry) learn from foreign firms through observation and imitation (or copying) product innovations, management novelties or improved forms of organization processes and adapting them to suit local conditions. Ideally, this diffusion of knowledge will have a positive impact on the local firms' productivity. Through interaction (both direct and indirect) with the MNCs and their affiliates, information is diffused and results in a higher chance of adoption by these locals [8]. As local firms observe the foreign firms (MNCs), they absorb knowledge like cheaper ways of production, management efficiencies, marketing strategies and others [21].

\section{Competition Effect (CE)}

The second channel in which technology diffuses into local firms is through the competitive pressure that the presence of foreign firms imposes on local firms. The competition effect (CE) forces local firms to operate more efficiently and productively so as to stay relevant or maintain their market share. The form of diffusion can either have a positive long-run effect and a negative short to medium term effect on local firms[3]. Aitken and Harrison[3]first documented negative spillover in intra-industry studies using data from Venezuela. CE occurs through the entry of multinationals who trade locally thereby increasing market size and competition in the local market. Countries with liberal trade policies may also experience this competition effect [21].

\section{FIGURE 3 TECHNOLOGY DIFFUSION CHART}

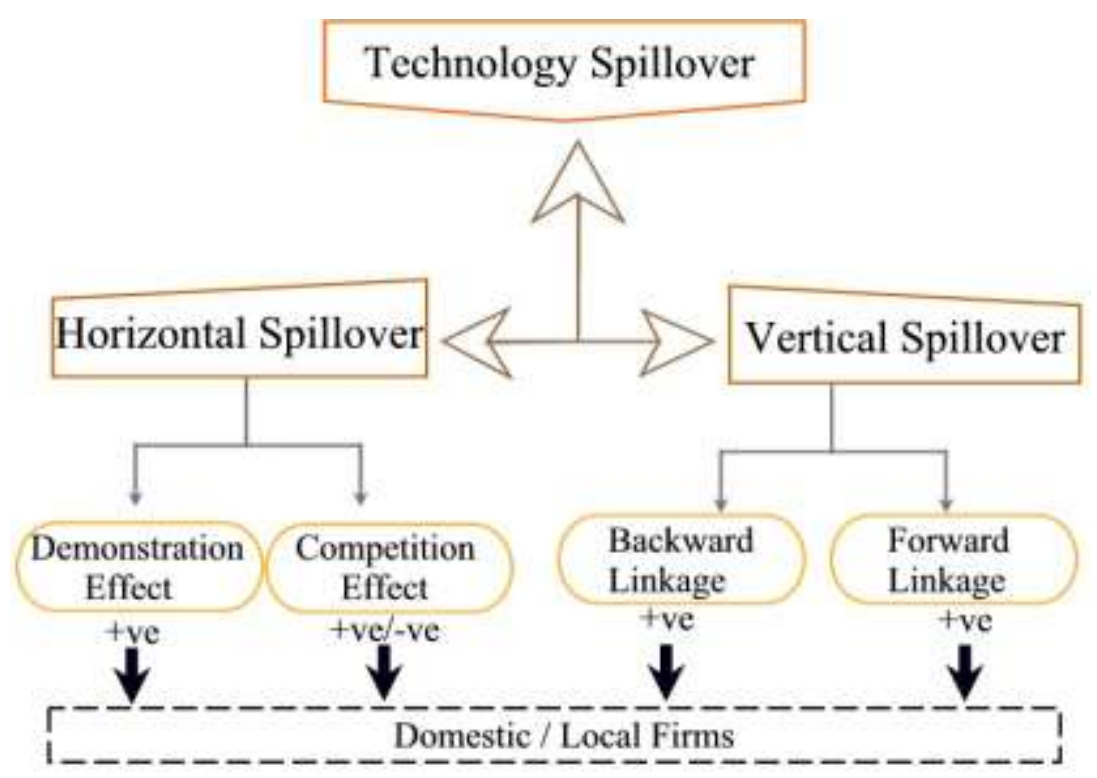

Chart showing Technology Diffusion to local or host firms (from top to bottom). Source: Author's own computation 


\section{B. $\quad$ Vertical spillovers}

The other side of the technology diffusion spectrum is through Vertical spillover from MNCs to domestic correspondents and vice versa. This form of diffusion occurs inter-industry across separate industries in the production line. The MNCs and the local firm are not competitors in this case. For there to exist some chance of technology transfer, the local and foreign firm must complement each other in the production cycle. The nature of their business should be such that at least one has to depend on the other for production. Vertical technology diffusion can occur through Backward linkages (BL) - transfer of technology from the foreign buyer to the local supplier- and Forward linkages (FL) -transfer of technology from the foreign supplier to the local buyer [21].

\section{Backward Linkages $(B L)$}

Backward linkages occur when MNEs transfer technology directly to their local suppliers through technical training so that the quality of the supplies they need from them can be improved. The form of diffusion occurs because of the foreign firm's desire for quality supplies from the local firm to be used for production. Also as identified by [33], MNEs and local suppliers "closeness" may bring the foreign firms workers and local workers into contact which will create the opportunity for technology to diffuse to the local workers.

\section{2. $\quad$ Forward Linkages (FL)}

Forward linkages occur in situations where the MNCs are the suppliers and the local firms become the buyers. Local firms may receive training in best marketing and selling practices, technology and equipment from MNEs to enable them to produce effectively and at the required quality. The technology diffused is aimed at increasing sales of the local firms, so they too can buy supplies from the foreign firms. MNCs identify that their sales figure are tied to that of their buyers who are the local firms. Because their business success is tied to that of the local firms, they encourage effective production and marketing aspects of the production line of the domestic firms. So they diffuse technology to the local buyers through training them in sales and providing equipment to boost sales.

\section{TECHNOLOGY SPILLOVER THROUGH FOREIGN FIRM PRESENCE}

Some studies have sort to link foreign firm presence with the rate of spillover. Significantly more studies have been done here compared to the other studies on technology spillover. These studies have shown that so far as the foreign firm exists in the local environment, interacting with local participants, fighting for the same local resources, there is a significantly high chance of technology spillover([19], [24], [20]).

Pioneering work by [14]has shown that the presence of foreign investment (and foreign firms) give domestic firms more chance to observe the technology used by the foreign firms, which also affect their ability to improve their technology. A more recent study by [29] founda significant relationship between FDI inflow between the USA and Japan. But when they analyze FDI inflows between selected countries within the European Union, they find a weak relationship. They estimated three regression models each tackling one aspect of the study. One regression model analyzed FDI inflows entering Europe (European Community) from the United States (USA), another analyzed FDI inflows entering Europe from Japan, and the third analyzed FDI inflows coming from countries within the European Community. A 6 year period from 1984 to 1989 was used for the study, and the data collected was at the sectoral level and the countries involved were USA, Japan and the European Community (EC) consisting of United Kingdom (UK), Italy, France and Germany. They used R\&D expending as a proxy from measuring technology. Neven and Soitis[29] also stated after reviewing empirical literature that the social benefits of R\&D could be twice as beneficial to the private firms that undertake them. Lui [24] conducted similar research using data from 20,000 manufacturing firms in China. Using the panel data she finds that FDI lowers short term productivity and increases in the long run. The short-run growth reduces because, resources are committed to learning the new technology, out of the resources used for production. Thus, technology is expensive to learn or acquire and require some commitment of scarce resource. She uses an endogenous growth model to explain how FDI spillover technology. Mansfield [25] also provides proof that by the end of the year, the amount of technology from foreign 
firms that diffuses to local firms within the industry is about 70 percent. Only in some instances have technology diffusion been curtailed like in the case of the Exxon -Florio amendment and ICL acquisition of ICL by Fujitsu.

\section{FDI AND TECHNOLOGY TRANSFER THROUGH LABOUR MOBILITY}

Some studies have looked at technology spillover occurring as a result of labour mobility or worker turnover. Thus the idea that when workers leave organizations for another (in this case from an MNC to a local firm), there is a high probability that they will spillover technology they have absorbed from the previous employers ([18], [5]). Other studies have gone around this same idea but used a different approach. For example,[31] used wage differentials to measure mobility from MNCs to local firms. She samples employer-employee data from Brazil and found a positive relationship between the wages of workers and their prior experience with multinationals. Again[9] found a significant relationship between worker mobility and technology transfer. He sampled data from manufacturing firms based in South Korea. He found a significant transfer of technology into local firms when production managers who previously worked with multinationals left them to work in domestic plants. Pack [30], also found the same results using data from the Taiwanese chemical industry. He discovered in the data period he used (in the mid1980s), the number of engineers and specially trained workers who left MNCs to work in domestic firms washuge50 percent and 63 percent respectively. These skills will be absorbed by the domestic firms that hire them. Authors like[17] and[15] also support technology spillover through worker mobility. However, an older study by [16]found insignificant labour mobility of workers from MNCs to domestic firms using data from Kenyan firms.

\section{CONCLUSION}

This review highlights the importance of FDI inflows into Africa and its nexus with technological improvement. Primary due to the high cost of creating new technology, it becomes a challenge for Africa to create its own technology enhancing innovations. The paperhighlights key issues on technology spillover in Africa, evidencing that technology spillover from foreign Direct Investment could be an important means through which the technology gap between developed economies and the developing world could be bridged. But more questions need to be asked; do local firms have the know-how to extract this technology? Do MNCs actually allow their technology to be copied? Further research needs to be done to examine in details how effective the transfer channels are.

\section{REFERENCES}

[1] Adams, S. (2009). Foreign Direct investment, domestic investment, and economic growth in Sub-Saharan Africa. Journal of Policy Modeling. Vol (31), 939-949.

[2] Agbloyor, E. K., Gyeke-Dako, A., Kuipo, R., \& Abor, J. (2016). Foreign Direct Investment and Economic Growth in SSA: The Role of Institutions. Thunderbird International Business Review, 58, 479-497.

[3] Aitken, B. J., \& Harrison, A. E. (1999). Do domestic firms benefit from direct foreign investment? Evidence from Venezuela. American Economic Review 89(3), 605-618.

[4] Aseidu, E. (2002). On the Determinants of Foreign Direct Investment to Developing Countries: is Africa Different? World Development, $30(1), 107-119$.

[5] Balsvik, R. (2010). Is Labor Mobility a Channel for Spillovers from Multinationals? Evidence from Norwegian Manufacturing. Review of Economics and Statistics.

[6] Bartels, F. L., Kratzsch, S., \& Eicher, M. (2009). Foreign Direct Investment in Sub-Saharan Africa: Determinants and Location Decisions. Vienna: Research and Statistics Branch, UNIDO.

[7] Basu, P., Chakraborty, C., \&Reagle, D. (2003). Liberalization, FDI, and Growth in Developing Countries: A Panel Cointegration Approach. Economic Inquiry, 41(3), 510-516.

[8] Blomstrom, M., \&Kokko, A. (1996). Multinational corporations and spillovers. Journal of Economic Surveys, 12(2), 1-31.

[9] Bloom, M. (1992), Technological Change in the Korean Electronics Industry, OECD, Paris.

(C) 2019, IJSMS Page 22 
[10] Bwalya , S. M. (2006). Foreign direct investment and technology spillovers:Evidence from panel data analysis of manufacturingfirms in Zambia. Journal of Development Economics, 81, 514-526.

[11] Choe, J. I. (2003). Do foreign direct investment and gross domestic investment promote economic growth?.Review of Development Economics, 7(1), 44-57.

[12] Dunning, J. (1992). Multinational Enterprises and Global Economy.

[13] Dutse, A. Y. (2012). Technological Capabilities and FDI-related Spillover: Evidence from Manufacturing Industries in Nigeria. American International Journal of Contemporary Research, 2(8), 201-211.

[14] Findlay, R. (1978). Relative Backwardness, Direct Foreign Investment, and the Transfer of Technology, A Simple Dynamic Model.Quarterly Journal of Economics 62, 1-16.

[15] Fosfuri, A., Motta, M., and Ronde, T. (2001). Foreign Direct Investment and Spillovers through Workers' Mobility. Journal of International Economics 53, 205-222.

[16] Gershenberg, I. (1987). The Training and Spread of Managerial Know-how: A Comparative Analysis of Multinational and Other Firms in Kenya.World Development. 15, 931-939.

[17] Glass, A. J., \&Saggi, K. (2002). Multinational Firms and Technology Transfer. Scandinavian Journal of Economics, $495-513$.

[18] Görg, H., \& Strobl, E. (2005). Spillovers from foreign firms through worker mobility: An empirical investigation. Scandinavian Journal of Economics, 107(4), 693-709.

[19] Griffith, T. L. (1999). Technology features as triggers for sensemaking. Academy of Management review, 24(3), $472-488$.

[20] Haskel, J. E., Pereira, S. C., Slaughter, M. J. (2002). Does inward FDI boost the productivity of domestic firms? Working paper No. 8724. NBER, London.

[21] Javorcik, B. S. (2010, September 3). Foreign Direct Investment and International Technology Transfer.

[22] Kombui, D. N., \& Kotey, R. A. (2019). Foreign Direct Investment in an Emerging Economy: Exploring the Determinants and Causal Linkages. Academic Journal of Economic Studies. Vol 5(1), pp. 51-62.

[23] Li, X., \& Liu, X. (2005). Foreign direct investment and economic growth: an increasingly endogenous relationship. World Development, 33(3), 393-407.

[24] Liu, Z. (2008). Foreign direct investment and technology spillovers:Theory and evidence. Journal of Development Economics 85 (2008), $176-193$.

[25] Mansfield, E. (1992). Appropriating the returns from investments in R\&D capital, in: K. Cool, D.J. Neven and I. Walter, European industrial restructuring in the 1990s. London: Macmillan.

[26] Mencinger, J. (2003). Does Foreign Direct Investment Always Enhance Economic Growth? Kyklos, 56(4), 491-508.

[27] Nair-Reichert, U., \&Weinhold, D. (2001). Causality Tests for Cross- Country Panels: A New Look at FDI and Economic Growth in Developing Countries. Oxford Bulletin of Economics and Statistics, 63(2), 153- 171.

[28] Nath, H. K. (2009). Trade, Foreign Direct Investment, and Growth: Evidence from Transition Economies. Comparative Economic Studies, $51(1), 20-50$.

[29] Neven, D., \&Siotis, G. (1996). Technology sourcing and FDI in the EC: An empirical evaluation. International Journal of Industrial Organization, (14), 543-560.

[30] Pack, H. (1997). The Role of Exports in Asian Development, in N. Birdsall and F. Jaspersen (eds.), Pathways to Growth: Comparing East Asia and Latin America, Inter- American Development Bank, Washington, DC. 
[31] Poole, Jennifer P. (2009). Knowledge Transfers from Multinational to Domestic Firms: Evidence from Worker Mobility. University of California, Santa Cruz.

[32] Sinani, E., \& Meyer, K. E. (2004). Spillovers of technology transfer from FDI: the case of Estonia. Journal of Comparative Economics(32), 445-466.

[33] Smarzynska, B. (2004). Does foreign direct investment increase the productivity of domestic firms? In search of spillovers through backward linkages. American economic review, 94(3), 605-627.

[34] UNCTAD. (2005). Economic development in Africa; Rethinking the Role of Foreign Direct Investment. United Nations Publications, Vol. Sales No. E.05.II.D.12 I. New York and Geneva. Doi:UNCTAD/GDS/AFRICA/2005/1

[35] UNCTAD. (2010). Foreign direct investment, the transfer and diffusion of technology, and sustainable development. United Nations Conference on Trade and Development, (p. TD/B/C.II/EM.2/2). Geneva.

[36] Zhang, K. H. (2001). Does Foreign Direct Investment Promote Economic Growth? Evidence from East Asia and Latin America. Contemporary Economic Policy, 19(2), 175-185. 